\title{
Environmental Informatics: Potentialities in iSchools and Information Science \& Technology Programs- An Analysis
}

\section{P. K. Paul ${ }^{1}$, Ricardo Saavedra ${ }^{2}$, P. S. Aithal ${ }^{3}$, Bashiru Aremu ${ }^{4}$, \& Pappachan}

\section{Baby $^{5}$}

${ }^{1}$ Executive Director, MCIS, Department of CIS, Information Scientist (Offg.), Raiganj University, India-733 134

${ }^{2}$ Director \& Chair, International Inter-University Programs, Azteca University, México, America

${ }^{3}$ Vice Chancellor, Srinivas University, Karnataka-574 146

${ }^{4}$ Vice Chancellor, Crown University, Intl. Chartered Inc. (CUICI) Argentina Campus, South

America-CP: 9400

${ }^{5}$ Head (Asian Region), Ballsbridge University, Dominica, North America-11019

Corresponding Author Email: pkpaul.infotech@gmail.com

Area/Section: Technology Management.

Type of the Paper: Exploratory Study.

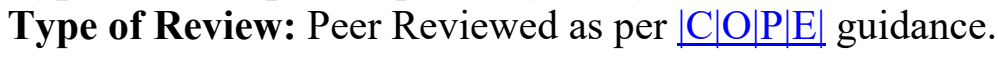

Indexed in: OpenAIRE.

DOI: http://doi.org/10.5281/zenodo.3841661.

Google Scholar Citation: IJMTS.

\section{How to Cite this Paper:}

Paul, P. K., Ricardo, Saavedra., Aithal, P. S., Bashiru, Aremu., \& Baby, Pappachan. (2020). Environmental Informatics: Potentialities in iSchools and Information Science \& Technology Programs - An Analysis. International Journal of Management, Technology, and Social Sciences (IJMTS), 5(1), 238-250. DOI: http://doi.org/10.5281/zenodo.3841661.

International Journal of Management, Technology, and Social Sciences (IJMTS)

A Refereed International Journal of Srinivas University, India.

(C) With Authors.

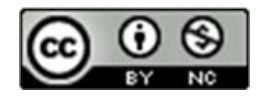

This work is licensed under a Creative Commons Attribution-Non-Commercial 4.0 International License subject to proper citation to the publication source of the work.

Disclaimer: The scholarly papers as reviewed and published by the Srinivas Publications (S.P.), India are the views and opinions of their respective authors and are not the views or opinions of the SP. The SP disclaims of any harm or loss caused due to the published content to any party. 


\title{
Environmental Informatics: Potentialities in iSchools and Information Science \& Technology Programs- An Analysis
}

\author{
P. K. Paul ${ }^{1}$, Ricardo Saavedra ${ }^{2}$, P. S. Aithal ${ }^{3}$, Bashiru Aremu ${ }^{4}$, \& Pappachan Baby ${ }^{5}$ \\ ${ }^{1}$ Executive Director, MCIS, Department of CIS, Information Scientist (Offg.), Raiganj University, \\ India-733 134 \\ ${ }^{2}$ Director \& Chair, International Inter-University Programs, Azteca University, México, America \\ ${ }^{3}$ Vice Chancellor, Srinivas University, Karnataka-574 146 \\ ${ }^{4}$ Vice Chancellor, Crown University, Intl. Chartered Inc. (CUICI) Argentina Campus, South \\ America-CP: 9400 \\ ${ }^{5}$ Head (Asian Region), Ballsbridge University, Dominica, North America-11019 \\ Corresponding Author Email: pkpaul.infotech@gmail.com
}

\begin{abstract}
Environment is an alarming concern and valuable to all of us, as all of us belong to the environment and ecology in a different context. There are different studies available related to the environment and as far as Informatics is concerned, it is the field of practice and study related to the information systems and information activities using tools, techniques and technologies. The applications of Informatics in different areas and branches are important concerns viz. agriculture, healthcare, transport and tourism, education and training, government and administration, business and commerce; and in this context Environmental Informatics are important. This is the application of Informatics and Information Technologies in the environment and allied subjects. There are universities and academic bodies offering Environmental Informatics academic programs mainly from the environment and allied departments and units. Though, the field is a combination of both the areas and thus can be offered in Informatics or allied departments or bodies. As far as Informatics related branches are concerned important are IT, Information Systems, Information Management, Computer Sciences, etc. And in all these departments or units Environmental Informatics can be started as a Major or Specialization with proper educational policies. iSchools is an international consortium and body dedicated to combining all information related institutes, departments and programs under one roof with a focus on technologies for the societies and different sectors. Thus, the field of Environmental Informatics can be started easily in the iSchools. Furthermore, in recent past iSchools considered as the academic units offering information or IT related programs irrespective of their affiliation to the iSchools Organization, United States. This is maybe considered as a policy paper for the environmentalist, educationalist, IT educators to think about the potentialities of Environmental Informatics in Informatics or IT or simply iSchools related departments, programs, etc.
\end{abstract}

Keywords: Environmental Informatics, IT, Computing, Environment, Interdisciplinary, Academic Innovation, iSchools.

\section{INTRODUCTION :}

During 1998 the iSchool originated by the following eminent educationalist and Information Professionals initially-

- Toni Carbo, School of Information Science, University of Pittsburgh;
- Donald Marchan, School of Information Studies, Syracuse University and

- Richard Lytle, College of Information Science and Technology, Drexel University

They have joined hands for building a common platform of information related departments or Information association called I-School Caucus. 
In 2001, 'Gang of Five' were noticeable from 'three' and later on in 2003 several Information related units joined and this way it creates a wider arena of diverse information system practice with keeping traditional information fundamentals. Some of the schools from the universities like University of North Carolina, Florida State University, Indiana University, University of Illinois, etc formed a group of ten. Later on, $I$ School teams changed the conventional name from I-School caucus to simply iSchools Organizations (i.e. Information Schools organization) with new and much more sophisticated agenda. As the organization is directly associated with the Information fields thus later on others including Computing, IT, Electronics and Telecommunication Schools joined with the iSchool Organization. As a result, different information related programs started in the units viz. 'Information Science and Technology, Information Management, Information Systems and Management and also existing Information Science with new flavor/ approaches and concentration [1], [13].

In these schools, different educational programs related to the information, technologies related to the information are offered. As Environmental Informatics is an interdisciplinary program, thus in such schools the programs may be offered at different levels and in different allied subfields of Environmental Informatics as well [2], [3], [14].

\section{OBJECTIVE :}

As this current paper is interdisciplinary and educational in nature; thus, inherit with the following aim and objectives-

- To learn about the basics of Environmental Informatics including its features, functions, and role.

- To know about the stakeholders, technologies involved, and current educational programs on Environmental Informatics.

- To get the broad picture of Informatics and allied fields and potentialities to offer Environmental Informatics in the Informatics and allied programs.

- To learn about the iSchools i.e. the consortium and also iSchools in general to oversee the potentialities of offering Environmental Informatics programs in the iSchools.

- To know about the current scenario of listed iSchools internationally including universities, academic bodies, and countries.

- To find out the possible specialization of Environmental Informatics in Information related units or programs i.e. iSchools and in iPrograms.

\section{METHODS :}

Current study entitled 'Environmental Informatics: Potentialities in iSchools and Information Science \& Technology Programs-An Analysis' is an interdisciplinary works and combines with different Informatics/ Information Technology, Environmental Science, Educational Science, Policy Studies etc. Thus, to do this study and analysis different sources are used to gather knowledge. It includes the secondary sources, primary sources. Further, studies undertaken using official website of iSchools Organization, United States to learn about the basic, latest on information related programs and potentialities on Environmental Informatics programs in the iSchools or any non-affiliating similar departments or departments. Government bodies related to the education, IT also analyzed to learn their recent academic activities and potentialities.

\section{ISCHOOLS, IST AND ENVIRONMENTAL INFORMATICS :}

Growing technological and management components changes the entire world of exiting Information Science and also its closest field. Information technology and Computing bring this changes many new knowledge gradients now associated with Information Science [5]], [9], [15]. Hence some of the Universities and Institutes focused on Information Science even started newer interdisciplinary and multidisciplinary component enriched Information Science and Technology, Information Science and Engineering, Information Science and Computing, Information Resource Management, Informatics etc [4], [7], [16].

It is worthy to note that, apart from nomenclature of Information Science and Technology many are offering different nomenclature but these are close with IST. The nomenclature of Information Science and Technology was first changed by the 
American Society of Information Science and Technology from American Society of Information Science. As this leading Information Science Association changed their title, so thereafter many universities, institutes, research center changed their nomenclature not only Information Science and Technology but also others, as mentioned previously. Ultimately these are all Information Science irrespective of their nomenclature [6], [8], [16].

The main features of such school are Information program concentration of interaction of 'Information-Technology-People'. All these are close to the society by the Information and Technology solution. To keep in mind interaction, need and trends this iSchools Organization established as international association in 1988 at United States (as name of iSchool caucus foundation initially) [10], [14], [17].

iSchool Organization is thus deals with the department or schools or institutions or colleges in Information Sciences ranging from simply Information Science/ Information Studies/ Communication Studies/ Information Systems/ Computing and Information Technology or any other field that is directly or indirectly related to Information and Computing for proper and scientific information solution and management [11], [16], [18].

As Information Science is also called as Informatics, so that in such schools the Environmental focused may be started. During this study it is noted that only few are offered the Geo Information Science/ Informatics specializations. Such potential schools with their current unit names (also universities) are listed in table: 1.

Table1 : List of iSchools registered under the iSchools Organization, United States

\begin{tabular}{|c|l|c|}
\hline SI.No. & \multicolumn{1}{|c|}{$\begin{array}{c}\text { University \& } \\
\text { Academic Unit } \\
\text { (iSchools) }\end{array}$} & Country \\
\hline 1 & $\begin{array}{l}\text { University at Albany, } \\
\text { College of Emergency } \\
\text { Preparedness, } \\
\text { Homeland Security and } \\
\text { Cybersecurity }\end{array}$ & USA \\
\hline 2 & $\begin{array}{l}\text { University of Arizona } \\
\text { School of Information }\end{array}$ & USA \\
\hline 3 & University of & USA \\
\hline
\end{tabular}

\begin{tabular}{|c|c|c|}
\hline & $\begin{array}{l}\text { California, Berkley } \\
\text { School of Information }\end{array}$ & \\
\hline 4 & $\begin{array}{l}\text { University of British } \\
\text { Colombia } \\
\text { The School of } \\
\text { Information }\end{array}$ & Canada \\
\hline 5 & $\begin{array}{l}\text { Carnegie Mellon } \\
\text { University } \\
\text { Heinz College of } \\
\text { Information Systems } \\
\text { and Public Policy }\end{array}$ & USA \\
\hline 6 & $\begin{array}{l}\text { University of Cincinnati } \\
\text { School of Information } \\
\text { Technology }\end{array}$ & USA \\
\hline 7 & $\begin{array}{l}\text { University of Colorado, } \\
\text { Department of } \\
\text { Information Science }\end{array}$ & USA \\
\hline 8 & $\begin{array}{l}\text { Cornell University } \\
\text { Faculty of Computing } \\
\text { and Information Science }\end{array}$ & USA \\
\hline 9 & $\begin{array}{l}\text { Dominican University } \\
\text { School of Information } \\
\text { Studies }\end{array}$ & USA \\
\hline 10 & $\begin{array}{l}\text { Drexel University } \\
\text { College Computing and } \\
\text { Informatics }\end{array}$ & USA \\
\hline 11 & $\begin{array}{l}\text { Florida State University } \\
\text { College of } \\
\text { Communication and } \\
\text { Information }\end{array}$ & USA \\
\hline 12 & $\begin{array}{l}\text { Georgia Institute of } \\
\text { Technology } \\
\text { College of Computing }\end{array}$ & USA \\
\hline 13 & $\begin{array}{l}\text { University of Illinois at } \\
\text { Urbana Champaign } \\
\text { School of Information } \\
\text { Sciences }\end{array}$ & USA \\
\hline 14 & $\begin{array}{l}\text { Indiana University at } \\
\text { IUPUI } \\
\text { School of Informatics } \\
\text { and Computing }\end{array}$ & USA \\
\hline 15 & $\begin{array}{l}\text { Indiana University, } \\
\text { Bloomington } \\
\text { School of Informatics, } \\
\text { Computing and } \\
\text { Engineering }\end{array}$ & USA \\
\hline 16 & $\begin{array}{l}\text { University of } \\
\text { California, Irvine } \\
\text { Donald Bren School of }\end{array}$ & USA \\
\hline
\end{tabular}

P. K. Paul., et al. (2020); www.srinivaspublication.com 


\begin{tabular}{|c|c|c|}
\hline & $\begin{array}{l}\text { Information and } \\
\text { Computer Science }\end{array}$ & \\
\hline 17 & $\begin{array}{l}\text { Kent State University } \\
\text { School of Information }\end{array}$ & USA \\
\hline 18 & $\begin{array}{l}\text { University of Kentucky } \\
\text { College of } \\
\text { Communications and } \\
\text { Information }\end{array}$ & USA \\
\hline 19 & $\begin{array}{l}\text { Long island University } \\
\text { University Palmer } \\
\text { School of Library and } \\
\text { Information Science }\end{array}$ & USA \\
\hline 20 & $\begin{array}{l}\text { Louisiana State } \\
\text { University } \\
\text { School of Library \& } \\
\text { Information Science }\end{array}$ & USA \\
\hline 21 & $\begin{array}{l}\text { University of Maryland, } \\
\text { Baltimore County } \\
\text { Department of } \\
\text { Information Systems }\end{array}$ & USA \\
\hline 22 & $\begin{array}{l}\text { University of Maryland } \\
\text { College of Information } \\
\text { Studies }\end{array}$ & USA \\
\hline 23 & $\begin{array}{l}\text { McGill University, } \\
\text { Montreal } \\
\text { School of Information } \\
\text { Studies }\end{array}$ & Canada \\
\hline 24 & $\begin{array}{l}\text { Michigan State } \\
\text { University } \\
\text { Department of Media } \\
\text { and Information }\end{array}$ & USA \\
\hline 25 & $\begin{array}{l}\text { University of Michigan } \\
\text { School of Information }\end{array}$ & USA \\
\hline 26 & $\begin{array}{l}\text { University of Missouri } \\
\text { School of Information } \\
\text { Science and Learning } \\
\text { Technologies }\end{array}$ & USA \\
\hline 27 & $\begin{array}{l}\text { University of Montréal } \\
\text { School of Library and } \\
\text { Information Science }\end{array}$ & Canada \\
\hline 28 & $\begin{array}{l}\text { University of North } \\
\text { Carolina, Chapel Hill } \\
\text { School of Information } \\
\text { and Library Science }\end{array}$ & USA \\
\hline 29 & $\begin{array}{l}\text { University of North } \\
\text { Texas } \\
\text { College of Information }\end{array}$ & USA \\
\hline 30 & $\begin{array}{l}\text { University of Oklahoma } \\
\text { School of Library and }\end{array}$ & USA \\
\hline
\end{tabular}

\begin{tabular}{|c|c|c|}
\hline & Information Studies & \\
\hline 31 & $\begin{array}{l}\text { The Pennsylvania State } \\
\text { University } \\
\text { College of Information } \\
\text { Science and Technology }\end{array}$ & USA \\
\hline 32 & $\begin{array}{l}\text { University of Pittsburg } \\
\text { School of Computing } \\
\text { and Information }\end{array}$ & USA \\
\hline 33 & $\begin{array}{l}\text { Pontifical Xavierian } \\
\text { University } \\
\text { Department of } \\
\text { Information Science }\end{array}$ & Colombia \\
\hline 34 & $\begin{array}{l}\text { Pratt Institute } \\
\text { School of Information }\end{array}$ & USA \\
\hline 35 & $\begin{array}{l}\text { The State University of } \\
\text { New Jersey, Rutgers, } \\
\text { School of } \\
\text { Communication and } \\
\text { Information }\end{array}$ & USA \\
\hline 36 & $\begin{array}{l}\text { San Jose State } \\
\text { University } \\
\text { School of Information }\end{array}$ & USA \\
\hline 37 & $\begin{array}{l}\text { University of São Paulo } \\
\text { School of } \\
\text { Communication and } \\
\text { Arts (ECA) }\end{array}$ & Brazil \\
\hline 38 & $\begin{array}{l}\text { Simmons University, } \\
\text { Boston } \\
\text { School of Library and } \\
\text { Information Science }\end{array}$ & USA \\
\hline 39 & $\begin{array}{l}\text { University of South } \\
\text { Carolina } \\
\text { School of Library and } \\
\text { Information Science }\end{array}$ & USA \\
\hline 40 & $\begin{array}{l}\text { University of South } \\
\text { Florida } \\
\text { School of Information }\end{array}$ & USA \\
\hline 41 & $\begin{array}{l}\text { State University of New } \\
\text { York, Buffalo } \\
\text { Department of } \\
\text { Information Science }\end{array}$ & USA \\
\hline 42 & $\begin{array}{l}\text { Syracuse University } \\
\text { School of Information } \\
\text { Studies }\end{array}$ & USA \\
\hline 43 & $\begin{array}{l}\text { The University of } \\
\text { Tennessee } \\
\text { School of Information } \\
\text { Sciences }\end{array}$ & USA \\
\hline 44 & Texas A\&M University & USA \\
\hline
\end{tabular}




\begin{tabular}{|c|c|c|}
\hline & $\begin{array}{l}\text { - Kingsville } \\
\text { Department of } \\
\text { Electrical Engineering } \\
\text { \& Computer Science }\end{array}$ & \\
\hline 45 & $\begin{array}{l}\text { University of Texas at } \\
\text { Austin } \\
\text { School of Information }\end{array}$ & USA \\
\hline 46 & $\begin{array}{l}\text { University of Toronto } \\
\text { Faculty of Information }\end{array}$ & USA \\
\hline 47 & $\begin{array}{l}\text { University of California } \\
\text { at Los Angles } \\
\text { Graduate School of } \\
\text { Education and } \\
\text { Information Studies }\end{array}$ & USA \\
\hline 48 & $\begin{array}{l}\text { University of } \\
\text { Washington } \\
\text { The Information School }\end{array}$ & USA \\
\hline 49 & $\begin{array}{l}\text { Wayne State University } \\
\text { School of Information } \\
\text { Sciences }\end{array}$ & USA \\
\hline 50 & $\begin{array}{l}\text { University of } \\
\text { Wisconsin, Madison } \\
\text { The Information School }\end{array}$ & USA \\
\hline 51 & $\begin{array}{l}\text { University of } \\
\text { Wisconsin, Milwaukee } \\
\text { School of Information } \\
\text { Studies }\end{array}$ & USA \\
\hline \multicolumn{3}{|c|}{ EuropeaniSchools Directory } \\
\hline 52 & $\begin{array}{l}\text { Aalborg University } \\
\text { Department of } \\
\text { Communication and } \\
\text { Psychology }\end{array}$ & Denmark \\
\hline 53 & $\begin{array}{l}\text { University of } \\
\text { Amsterdam } \\
\text { Graduate School of } \\
\text { Humanities, Archives } \\
\text { and Information Studies }\end{array}$ & Netherlands \\
\hline 54 & $\begin{array}{l}\text { Bar-Ilan University } \\
\text { Department of } \\
\text { Information Science }\end{array}$ & Israel \\
\hline 55 & $\begin{array}{l}\text { University of Borås } \\
\text { The Swedish School of } \\
\text { Library and Information } \\
\text { Science }\end{array}$ & Sweden \\
\hline 56 & $\begin{array}{l}\text { University Carlos III of } \\
\text { Madrid } \\
\text { Department of Library } \\
\text { and Documentation }\end{array}$ & Spain \\
\hline 57 & Open University of & Spain \\
\hline
\end{tabular}

\begin{tabular}{|c|c|c|}
\hline & $\begin{array}{l}\text { Catalonia } \\
\text { Faculty of Computer } \\
\text { Science, Multimedia } \\
\text { and } \\
\text { Telecommunications. }\end{array}$ & \\
\hline 58 & $\begin{array}{l}\text { Charles University in } \\
\text { Prague } \\
\text { Institute of Information } \\
\text { Studies and } \\
\text { Librarianship (IISL) }\end{array}$ & $\begin{array}{c}\text { Czech } \\
\text { Republic }\end{array}$ \\
\hline 59 & $\begin{array}{l}\text { University of } \\
\text { Copenhagen } \\
\text { Department of } \\
\text { Information Studies }\end{array}$ & Denmark \\
\hline 60 & $\begin{array}{l}\text { University College } \\
\text { Dublin } \\
\text { School of Information } \\
\text { and Communication } \\
\text { Studies }\end{array}$ & Ireland \\
\hline 61 & $\begin{array}{l}\text { University of Glasgow } \\
\text { Humanities Advanced } \\
\text { Technology and } \\
\text { Information Institute }\end{array}$ & UK \\
\hline 62 & $\begin{array}{l}\text { Hacettepe University } \\
\text { Department of } \\
\text { Information } \\
\text { Management }\end{array}$ & Turkey \\
\hline 63 & $\begin{array}{l}\text { Humboldt University of } \\
\text { Berlin } \\
\text { Berlin School of } \\
\text { Library and Information } \\
\text { Science }\end{array}$ & Germany \\
\hline 64 & $\begin{array}{l}\text { IMT Atlantique (A } \\
\text { Technological } \\
\text { University) } \\
\text { Department of Logic } \\
\text { Uses, Social Sciences } \\
\text { and Information }\end{array}$ & France \\
\hline 65 & $\begin{array}{l}\text { Linnaeus University } \\
\text { Information Institute } \\
\text { (iInstitute) }\end{array}$ & Sweden \\
\hline 66 & $\begin{array}{l}\text { University College } \\
\text { London } \\
\text { Department of } \\
\text { Information Studies }\end{array}$ & $\begin{array}{c}\text { United } \\
\text { Kingdom }\end{array}$ \\
\hline 67 & $\begin{array}{l}\text { Makerere University } \\
\text { The College of } \\
\text { Computing and } \\
\text { Information Sciences }\end{array}$ & Uganda \\
\hline
\end{tabular}




\begin{tabular}{|c|c|c|}
\hline 68 & $\begin{array}{l}\text { Northumbria University } \\
\text { Department of } \\
\text { Computing and } \\
\text { Information Sciences }\end{array}$ & $\begin{array}{l}\text { United } \\
\text { Kingdom }\end{array}$ \\
\hline 69 & $\begin{array}{l}\text { Nova University } \\
\text { Lisabon } \\
\text { Information } \\
\text { Management School }\end{array}$ & Portugal \\
\hline 70 & $\begin{array}{l}\text { Manchester } \\
\text { Metropolitan University } \\
\text { Information and } \\
\text { Communications }\end{array}$ & $\begin{array}{l}\text { United } \\
\text { Kingdom }\end{array}$ \\
\hline 71 & $\begin{array}{l}\text { The University of } \\
\text { Minho } \\
\text { ALGORITMI Center } \\
\text { School of Engineering }\end{array}$ & Portugal \\
\hline 72 & $\begin{array}{l}\text { Oslo Metropolitan } \\
\text { University } \\
\text { Department of } \\
\text { Archivistics, Library } \\
\text { and Information Science }\end{array}$ & Norway \\
\hline 73 & $\begin{array}{l}\text { University of Oxford } \\
\text { The Oxford Digital } \\
\text { Information Group }\end{array}$ & Oxford \\
\hline 74 & $\begin{array}{l}\text { Polytechnic University } \\
\text { of Valencia } \\
\text { School of Informatics }\end{array}$ & Spain \\
\hline 75 & $\begin{array}{l}\text { University of Porto } \\
\text { Faculty of Engineering } \\
\text { in cooperation with the } \\
\text { Faculty of Arts }\end{array}$ & Portugal \\
\hline 76 & $\begin{array}{l}\text { University of } \\
\text { Regensburg } \\
\text { Institute for Information } \\
\text { and Media, Language } \\
\text { and Culture }\end{array}$ & Germany \\
\hline 77 & $\begin{array}{l}\text { Robert Gordon } \\
\text { University } \\
\text { Department of } \\
\text { Information } \\
\text { Management of } \\
\text { Aberdeen Business } \\
\text { School }\end{array}$ & $\begin{array}{c}\text { United } \\
\text { Kingdom }\end{array}$ \\
\hline 78 & $\begin{array}{l}\text { University of Sheffield } \\
\text { Information School }\end{array}$ & $\begin{array}{c}\text { United } \\
\text { Kingdom }\end{array}$ \\
\hline 79 & $\begin{array}{l}\text { University of Siegen } \\
\text { School of Media and } \\
\text { Information (iSchool) }\end{array}$ & Germany \\
\hline 80 & University of & United \\
\hline
\end{tabular}

\begin{tabular}{|c|c|c|}
\hline & $\begin{array}{l}\text { Strathclyde } \\
\text { Computer and } \\
\text { Information Sciences }\end{array}$ & Kingdom \\
\hline 81 & $\begin{array}{l}\text { Josip Juray Strossmayer } \\
\text { University of Osijek, } \\
\text { Croatia } \\
\text { Department of } \\
\text { Information Sciences }\end{array}$ & Croatia \\
\hline 82 & $\begin{array}{l}\text { Tampere University } \\
\text { Faculty of IT and } \\
\text { Communication } \\
\text { Sciences }\end{array}$ & Finland \\
\hline \multicolumn{3}{|c|}{ Asia Pacific iSchools Directory } \\
\hline 83 & $\begin{array}{l}\text { Central China Normal } \\
\text { University } \\
\text { School of Information } \\
\text { Management }\end{array}$ & China \\
\hline 84 & $\begin{array}{l}\text { Charles Sturt University } \\
\text { School of Information } \\
\text { Studies }\end{array}$ & Australia \\
\hline 85 & $\begin{array}{l}\text { University of the } \\
\text { Chinese Academy of } \\
\text { Sciences } \\
\text { Department of Library, } \\
\text { Information and } \\
\text { Archives Management }\end{array}$ & China \\
\hline 86 & $\begin{array}{l}\text { University of Hong } \\
\text { Kong } \\
\text { Human } \\
\text { Communication, } \\
\text { Development, and } \\
\text { Information Sciences } \\
\text { (CDIS) }\end{array}$ & China \\
\hline 87 & $\begin{array}{l}\text { Jilin University } \\
\text { School of Management }\end{array}$ & China \\
\hline 88 & $\begin{array}{l}\text { KhonKaen University } \\
\text { (KKU) } \\
\text { Department of } \\
\text { Information Science }\end{array}$ & Thailand \\
\hline 89 & $\begin{array}{l}\text { Kyungpook National } \\
\text { University (KNU) } \\
\text { Department of Library } \\
\text { and Information Science }\end{array}$ & Korea \\
\hline 90 & $\begin{array}{l}\text { Kyushu University } \\
\text { Department of Library } \\
\text { Science, Graduate } \\
\text { School of Integrated } \\
\text { Frontier Sciences }\end{array}$ & Japan \\
\hline 91 & National Chengchi & Taiwan \\
\hline
\end{tabular}




\begin{tabular}{|c|c|c|}
\hline & $\begin{array}{l}\text { University } \\
\text { Graduate Institute of } \\
\text { Library Information and } \\
\text { Archival Studies }\end{array}$ & \\
\hline 92 & $\begin{array}{l}\text { Nanjing University of } \\
\text { Science and Technology } \\
\text { School of Economics } \\
\text { and Management }\end{array}$ & China \\
\hline 93 & $\begin{array}{l}\text { Nanjing University } \\
\text { School of Information } \\
\text { Management }\end{array}$ & China \\
\hline 94 & $\begin{array}{l}\text { Monash University } \\
\text { Faculty of Information } \\
\text { Technology }\end{array}$ & Australia \\
\hline 95 & $\begin{array}{l}\text { University of } \\
\text { Melbourne } \\
\text { Department of } \\
\text { Computing \& } \\
\text { Information Systems }\end{array}$ & Australia \\
\hline 96 & $\begin{array}{l}\text { National Taiwan } \\
\text { University } \\
\text { Department and } \\
\text { Graduate Institute of } \\
\text { Library and Information } \\
\text { Science }\end{array}$ & Taiwan \\
\hline 97 & $\begin{array}{l}\text { National Taiwan } \\
\text { Normal University } \\
\text { Graduate Institute of } \\
\text { Library and Information } \\
\text { Studies }\end{array}$ & Taiwan \\
\hline 98 & $\begin{array}{l}\text { Renmin University of } \\
\text { China } \\
\text { School of Information } \\
\text { Resource Management }\end{array}$ & China \\
\hline 99 & $\begin{array}{l}\text { Shanghai University } \\
\text { Department of Library, } \\
\text { Information and } \\
\text { Archives }\end{array}$ & China \\
\hline 100 & $\begin{array}{l}\text { Soochow University } \\
\text { Department of archives } \\
\text { and e-government }\end{array}$ & China \\
\hline 101 & $\begin{array}{l}\text { University of South } \\
\text { Australia } \\
\text { School of Information } \\
\text { Technology \& } \\
\text { Mathematical Sciences }\end{array}$ & Australia \\
\hline 102 & $\begin{array}{l}\text { National Taiwan } \\
\text { University } \\
\text { Department and }\end{array}$ & Taiwan \\
\hline
\end{tabular}

\begin{tabular}{|c|c|c|}
\hline & $\begin{array}{l}\text { Graduate Institute of } \\
\text { Library and Information } \\
\text { Science }\end{array}$ & \\
\hline 103 & $\begin{array}{l}\text { Peking University } \\
\text { Department of } \\
\text { Information } \\
\text { Management }\end{array}$ & China \\
\hline 104 & $\begin{array}{l}\text { University of the } \\
\text { Philippines } \\
\text { School of Library and } \\
\text { Information Studies }\end{array}$ & Philippines \\
\hline 105 & $\begin{array}{l}\text { Sun Yat-Sen University } \\
\text { School of Information } \\
\text { Management }\end{array}$ & China \\
\hline 106 & $\begin{array}{l}\text { Sungkyunkwan } \\
\text { University } \\
\text { Library and Information } \\
\text { Science }\end{array}$ & $\begin{array}{l}\text { South } \\
\text { Korea }\end{array}$ \\
\hline 107 & $\begin{array}{l}\text { University of } \\
\text { Technology, Malaysia } \\
\text { (MARA) } \\
\text { Faculty of Information } \\
\text { Management }\end{array}$ & Malaysia \\
\hline 108 & $\begin{array}{l}\text { University of Tsukuba } \\
\text { Graduate School of } \\
\text { Library, Information, } \\
\text { and Media Studies }\end{array}$ & Japan \\
\hline 109 & $\begin{array}{l}\text { Waikato University } \\
\text { School of Computing } \\
\text { and Mathematical } \\
\text { Sciences }\end{array}$ & $\begin{array}{c}\text { New } \\
\text { Zealand }\end{array}$ \\
\hline 110 & $\begin{array}{l}\text { Wuhan University } \\
\text { School of Information } \\
\text { Management }\end{array}$ & China \\
\hline 111 & $\begin{array}{l}\text { Yonsei University } \\
\text { Department of Library } \\
\text { and Information Science }\end{array}$ & $\begin{array}{l}\text { South } \\
\text { Korea }\end{array}$ \\
\hline
\end{tabular}

\section{ENVIRONMENTAL INFORMATICS POTENTIALITIES IN ISCHOOLS OR IN IST RELATED DEPARTMENTS/ UNITS :}

Environmental Informatics is interdisciplinary practicing domain and responsible for the utilization of Information Technology and Computing in Environment and related subjects dedicated to the Nature and Ecology [12], [19. Moreover, areas such as Geology, Agriculture, Forestry, Geography, Climatology, Oceanography, 
etc are also important users of Environmental Informatics. It is also called as Eco Informatics and Ecology Informatics in some contexts. Environmental Informatics is also related with Environmental Information Technology. Environmental Informatics build with environmental and information sciences for problem solving to the environment, humans and computers [6], [20], [21].

The iSchools are focused on information sciences or technologies related to the information. Hence simply such can be depicted as Information Science and Technology programs. Environmental Informatics as an interdisciplinary [7], 22], [24] programs combine with environment and information technology. Thus, there are huge potentially to offer Environmental Informatics or related subjects in the iSchools listed by the iSchools Organization, United States if possible. However, in other schools or departments related to the information or IT Environmental Informatics programs can be started. The general degrees in iSchools are-
- $\mathrm{BSc} / \mathrm{MSc}$

- $\mathrm{BS} / \mathrm{MS}$

- MPS

- $\mathrm{PhD}$, etc

In Informatics/Information Science ProgramsInformatics is synonym with the Information Science in some context. Both are information centric and application oriented [4], [23], [26]. Informatics is particularly mean as a practicing field while Information Science can be denoted as a field of study. In this field growing domain or field specific areas are include-

- Health Informatics

- Bio Informatics

- Geo Informatics

- Business Informatics, etc

Internationally most of these branches available with $\mathrm{BSc} / \mathrm{BS} / \mathrm{MSc} / \mathrm{MS}$ Degree while in India and some other countries the branches can be offered in Engineering context as well. The table2 depicted such possible programs herewith on Environmental Informatics concentrated.

Table2: Possible programs with Environmental Informatics concentration in Informatics Programs

\begin{tabular}{|l|l|}
\hline Science Concentration (Informatics) & Engineering Concentration (Informatics) \\
\hline BS-Informatics (Environmental Informatics) & BTech/BE-Informatics (Environmental \\
BSc-Informatics (Environmental Informatics) & Informatics) \\
MS-Informatics (Environmental Informatics) & MTech/ME-Informatics (Environmental \\
MSc-Informatics (Environmental Informatics) & Informatics) \\
MPhil-Informatics (Environmental Informatics) & MSc (Engg.) -Informatics (Environmental \\
PhD/DSc-Informatics (Environmental Informatics) & Informatics) \\
& MPhil (Engg)-Informatics (Environmental \\
& Informatics) \\
& PhD/DSc (Engg.) -Informatics \\
& (Environmental Informatics) \\
\hline
\end{tabular}

\section{In Information Systems Programs-}

The field Information Systems is very close with Information Science or Informatics. This is the branch responsible for designing, developing and implementing IT and Systems for the organizations and institutes [16], [17]. The field is concentrated on different organizational and business-related aspects as well. The common degrees in this field are BSc/BS/MSc/MS Degree. As far as Engineering is concerned, the table 3 depicted possible specializations of Environmental Informatics.

Table 3: Possible programs with Environmental Informatics concentration in Information Systems Programs

\begin{tabular}{|l|l|}
\hline Science Concentration (Information Systems) & $\begin{array}{l}\text { Engineering Concentration (Information } \\
\text { Systems) }\end{array}$ \\
\hline BS- Information Systems (Environmental & BTech/BE-Information Systems (Environmental \\
\hline
\end{tabular}




\begin{tabular}{l}
\hline Informatics) \\
BSc- Information Systems (Environmental \\
Informatics) \\
MS- Information Systems (Environmental \\
Informatics) \\
MSc- Information Systems (Environmental \\
Informatics) \\
MPhil- Information Systems (Environmental \\
Informatics) \\
PhD/DSc-Informatics (Environmental Informatics)
\end{tabular}

In Information Management Programs-

Environmental Informatics branch or specializations can be started in Information Management Degrees. Information Management is responsible for the managing information of different systems or organizations using various

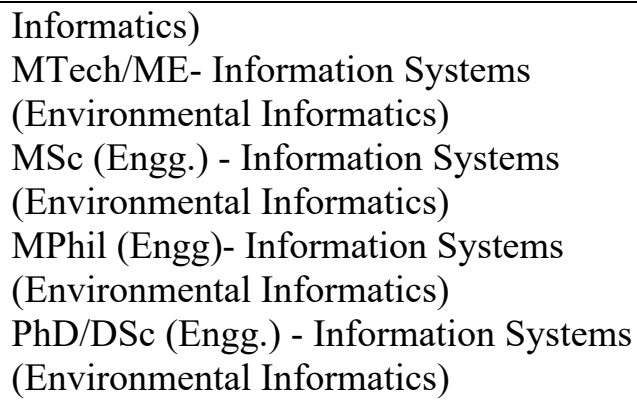

tools, systems. The possible programs in Information Management with Environmental Informatics concentration is depicted table 4 herewith.

Table 4: Possible programs with Environmental Informatics concentration in Information Systems Programs

\begin{tabular}{l} 
Science Concentration (Information \\
Management) \\
\hline BS- Information Management (Environmental \\
Informatics) \\
BSc- Information Management (Environmental \\
Informatics) \\
MS- Information Management (Environmental \\
Informatics) \\
MSc- Information Management (Environmental \\
Informatics) \\
MPhil- Information Management (Environmental \\
Informatics) \\
PhD/DSc-Informatics (Environmental \\
Informatics)
\end{tabular}

Engineering Concentration (Information Systems)

BTech/BE-Information Management

(Environmental Informatics)

MTech/ME-Information Management

(Environmental Informatics)

MSc (Engg.) -Information Management

(Environmental Informatics)

MPhil (Engg)-Information Management

(Environmental Informatics)

$\mathrm{PhD} / \mathrm{DSc}$ (Engg.) -Information Management

(Environmental Informatics)

\section{In Computer Sciences-}

In academics as far as, Computing field is concerned there are many subjects viz. Computer Science, Computer Engineering, Computing, Computer Applications etc. Ultimately these subjects are responsible for designing, development and applications of computer systems. These are mainly hardware centric. But still, within this category most suitable subjects in which Environmental Informatics specializations can be started are Computing, Computer Applications. Though in Computer Science, Computer Engineering, etc the specializations of Environmental Informatics can be started for providing the solutions of software development responsible for the environmental solutions. Table 5 herewith depicted in detail.

Table 5: Possible programs with Environmental Informatics concentration in Computing related Sciences Programs

\begin{tabular}{|c|c|}
\hline $\begin{array}{c}\text { Science Concentration } \\
\text { (Computer Sciences) }\end{array}$ & $\begin{array}{c}\text { Engineering Concentration } \\
\text { (Computer Sciences) }\end{array}$ \\
\hline BS- Computer Science (Environmental & BTech/BE-Computer Science (Environmental \\
\hline
\end{tabular}




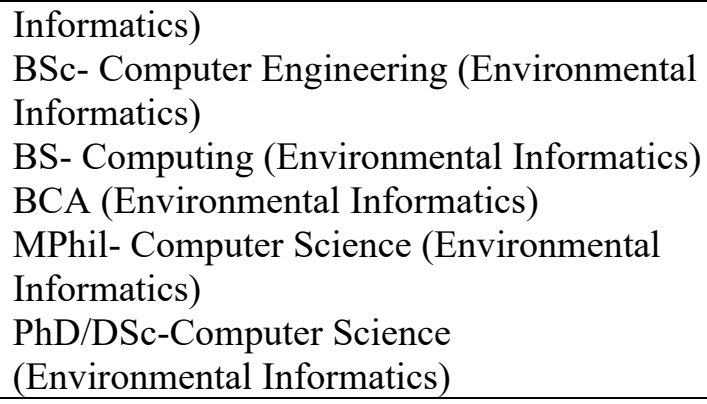

\section{In Emerging Technologies as research focus-}

Environmental Informatics as a sub field of Informatics is also depends on various emerging technologies viz. -

- Big Data Management.

- Data Analytics.

- Cloud Computing.

- Virtualization Applications.

- Internet of Things (IoT).

- Converged Network.

- User Experience Designing.

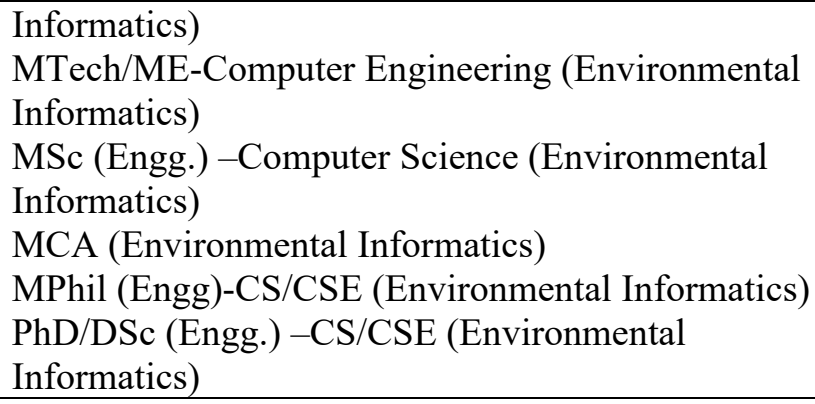

- Usability Engineering.

- Human Computer Interaction.

- 3D Graphics and Media.

- Wireless Network and Censor.

- Satellite Technology, etc.

And all these technologies can be applied in different areas of Environmental Informatics for better environmental solutions. Some of the possible programs in this regard depicted in Table 6 herewith.

Table 6: Possible emerging technologies with Environmental Informatics concentration

\begin{tabular}{|l|l|}
\hline \multicolumn{1}{|c|}{$\begin{array}{c}\text { Science Concentration } \\
\text { Emerging Technologies) }\end{array}$} & \multicolumn{1}{c|}{$\begin{array}{c}\text { Engineering Concentration } \\
\text { (Emerging Technologies) }\end{array}$} \\
\hline BSc Data Science (Environmental Informatics) & BTech/ BE-Data Science \\
MSc Data Science (Environmental Informatics) & (Environmental Informatics) \\
MPhil/PhD Data Science (Environmental & BTech/BE- Data Science \\
Informatics) & (Environmental Informatics) \\
& BTech/BE- \\
& Data Science (Environmental Informatics) \\
\hline
\end{tabular}

\section{SUGGESTION :}

- Environmental Informatics as inter-disciplinary thus apart from the environment related programs it can be started at informatics or information science and technology related programs as specilizations/concentration at Bachelors or Masters or Research levels by adding professors and professionals from the field/s.

- The departments or academic units which offers IT or Computing related department can start fullfledged Environmental Informatics programs as Bachelors, Masters and Doctoral Degrees.

- The schools i.e. iSchools Organization listed already offers wide range of IT, informatics programs on different technologies and domain centric programs and in some of these institutes the specilizations of Environmental Informatics or full-fledged Environmental Informatics could be started.

- The departments, schools or academic bodies follows the programs and academic attributes related to the iSchools Organization listed schools but not under this consortium may also start this specilization by taking measure on proper policies and arrangement. And in a country like India as well this type of procedure would be suitable.

- In case of health infrastructure of environment or allied branches Environmental Informatics allied subjects can be started viz. Forest Informatics, Irrigation Informatics, Ecology Informatics, etc based on need and potentialities.

- In case of difficulties in academic programs offering the institutes can offer Environmental Informatics as a research major and easily started. 


\section{CONCLUSION :}

World is changing and uncountable changes in different sectors and spaces are noticeable. All we belong to the society and this is a valuable part of the environment. Practically the Societal development can lead the Environmental Development in many contexts. Different weapons, tools, techniques, etc are useful in environmental monitoring and systems. 'Environmental Informatics' is become an important name for modern environmental practice. Environmental Informatics is concerned with the utilizations of Information technologies in environment as well natural resource management in different way. The educational programs on Environmental Informatics are an important step at this moment. The iSchools both under listed of iSchools Organizations and non-listed but following such approaches can move to start educational programs, major, minors, specializations and research areas leading to research degrees on the Environmental Informatics or allied areas. Further, it is important to note that the institutes already have Geo Informatics or allied subjects can easily started educational programs on Environmental Informatics.

\section{REFERENCES :}

[1] Allen T. F. Giampietro M. \& Little A. M. (2003). Distinguishing ecological engineering from environmental engineering. Ecological Engineering, 20(5) 389-407.

[2] Chu, H. (2012). iSchools and non-iSchools in the USA: An examination of their master's programs. Education for information, 29(1), 1-17.

[3] Dayal, I. (2002). Developing management education in India. Journal of management Research, 2(2), 98.

[4] Dillon, A. (2012). What it means to be an iSchool. Journal of Education for Library and Information Science, 53(4), 267.

[5] Goldberg-Kahn, B., \& Healy, J. C. (1997). Medical informatics training in pathology residency programs. American journal of clinical pathology, 107(1), 122-127.

[6] Gupta, D., \& Gupta, N. (2012). Higher education in India: structure, statistics and challenges. Journal of education and Practice, 3(2). 17-24.

[7] Henricks, W. H., Boyer, P. J., Harrison, J. H., Tuthill, J. M., \& Healy, J. C. (2003). Informatics training in pathology residency programs: proposed learning objectives and skill sets for the new millennium. Archives of pathology \& laboratory medicine, 127(8), 1009-1018.

[8] Hjorland, B., \& Albrechtsen, H. (1995). Toward a new horizon in information science: domain-analysis. Journal of the American Society for Information Science (1986-1998), 46(6), 400.

[9] Kapur, D., \& Mehta, P. B. (2004). Indian higher education reform: From half-baked socialism to half-baked capitalism. Center for international development working paper, 103.

[10[ Michael Buckland and Ziming liu (1995).History of information science. Annual Review of Information Science and Technology, 30(1), 385-416.

[11] Nambissan, G. B., \& Rao, S. (Eds.). (2013). Sociology of education in India: Changing contours and emerging concerns. New Delhi: Oxford University Press.

[12] Nikolov, R. (1987). Integrating informatics into the curriculum. Education and Computing, 3(3), 269-74.

[13] Pau1, Prantosh Kumar and Sridevi, K V (2012). I Schools: An overview emphasizing need of versatile I-Programme in India: A Study. International Journal of Embedded Systems and Computer Engineering, 4(2), 133-137.

[14] Paul, Prantosh Kumar(2013). Business Informatics: Emerging Domain of Interdisciplinary Information Science with Possibilities in ISchools. International Journal of Marketing Theory, 3(2), 113-120.

[15] Paul, Prantosh Kumar, Dipak Chatterjee, Ajay Kumar (2013). Geographical Information System and its specialization requirement in I- schools [Information Schools]. The Sci-Tech International Journal of Engineering Sciences,1(1), 88-95.

[16] Paul, Prantosh Kumar (2013). Business Informatics: Emerging Domain of Interdisciplinary Information Science with Possibilities in I- 
Schools. International Journal of Marketing Theory, 3(2), 113-120.

[17] Paul, Prantosh Kumar (2013). MScInformation Science [Geo Informatics]: Overview emphasizing twoproposed curriculum for sophisticated GeoSpatial development. International Journal of Pharmaceutical and Biological Research, 4(5), 218-227.

[18] Paul, Prantosh Kumar, Dipak Chaterjee (2013). Retail Informatics: The Wonderful Cluster of Information Science and Marketing Management. SIT Journal of Management, 3(11), 89-95.

[19] Paul, Prantosh Kumar, Jhuma Ganguly, M Ghosh (2013). Chemical Information Management powered by Chemo-Informatics: Possibilities and opportunities emphasizing need and way in Academics and Universities. Current Trends in Biotechnology and Chemical Research, 3(2), 137141.

[20] Paul, P.K. Aithal, P.S. (2017) Informatics as a Branch in Indian Academics with Case of Private Universities: Emphasizing Biological Information Sciences. Current Trends in Biotechnology and Chemical Research, 7(1-2), 37-42.

[21] Paul, P. K., Aithal, P. S., \& Bhuimali, A (2017). Business Informatics: A possible specialization of MSc-Information Science \& Technology (IST): Challenges and Opportunities in Developing Countries Context. International Journal of Recent Researches in Science, Engineering \& Technology. 5(10), 54-63.

[22] Paul, P. K., Aithal, P. S. \& Bhuimali, A. (2018). Business Informatics: With Special Reference to Big Data as an emerging Area: A Basic Review. International Journal of Recent Researches in Science, Engineering \& Technology 6(04), 21-27.

[23] Sood, R., \& Adkoli, B. V. (2000). Medical education in India-problems and prospects. $J$ Indian Acad Clin Med, 1(3), 210-212.
[24] Sohani, N., \& Sohani, N. (2012). Developing interpretive structural model for quality framework in higher education: Indian context. Journal of Engineering, Science \& Management Education, 5(2), 495-501.

[25] Tilak, J. B. (2008). Transition from higher education as a public good to higher education as a private good: The saga of Indian experience. Journal of Asian Public Policy, 1(2), 220-234.

[26] Wiggins, A., \& Sawyer, S. (2012). Intellectual diversity and the faculty composition of iSchools. Journal of the American Society for Information Science and Technology, 63(1), 8-21.

[27] Wu, D., He, D., Jiang, J., Dong, W., \& Vo, K. T. (2012). The state of iSchools: an analysis of academic research and graduate education. Journal of Information Science, 38(1), 15-36. 